University of Nebraska - Lincoln

DigitalCommons@University of Nebraska - Lincoln

\title{
Weed Suppression by Deleterious Rhizobacteria is Affected by Formulation and Soil Properties
}

\author{
Robert E. Zdor \\ Andrews University \\ Carlene M. Alexander \\ Andrews University \\ Robert J. Kremer \\ University of Missouri - Columbia, KremerR@missouri.edu
}

Follow this and additional works at: https://digitalcommons.unl.edu/usdaarsfacpub

Part of the Agricultural Science Commons

Zdor, Robert E.; Alexander, Carlene M.; and Kremer, Robert J., "Weed Suppression by Deleterious Rhizobacteria is Affected by Formulation and Soil Properties" (2005). Publications from USDA-ARS / UNL Faculty. 548.

https://digitalcommons.unl.edu/usdaarsfacpub/548

This Article is brought to you for free and open access by the U.S. Department of Agriculture: Agricultural Research Service, Lincoln, Nebraska at DigitalCommons@University of Nebraska - Lincoln. It has been accepted for inclusion in Publications from USDA-ARS / UNL Faculty by an authorized administrator of DigitalCommons@University of Nebraska - Lincoln. 
Communications in Soil Science and Plant Analysis, 36: 1289-1299, 2005

Copyright (C) Taylor \& Francis, Inc.

ISSN 0010-3624 print/1532-2416 online

DOI: $10.1081 / C S S-200056933$

\title{
Weed Suppression by Deleterious Rhizobacteria is Affected by Formulation and Soil Properties
}

\author{
Robert E. Zdor and Carlene M. Alexander \\ Department of Biology, Andrews University, Berrien Springs, \\ Michigan, USA \\ Robert J. Kremer \\ U.S. Department of Agriculture, Agricultural Research Service, and \\ Department of Soil, Environmental and Atmospheric Sciences, \\ University of Missouri, Columbia, Missouri, USA
}

\begin{abstract}
Deleterious rhizobacteria (DRB) suppress weed growth in field tests and are considered potential weed biological control agents. This study compared the relative inhibitory action of the DRB Pseudomonas fluorescens strain G2-11 in different formulations, corn gluten meal (CGM), and semolina flour, toward wheat (Triticum aestivum L.), green foxtail (Setaria viridis (L.) Beauv.), and velvetleaf (Abutilon theophrasti Medik) seeds and seedlings in soil assays. Strain G2-11 successfully established in semolina flour as an inoculum formulation but was incompatible with CGM presumably because of antibacterial factors present. The effect of DRB and plant products on seed germination and plant growth were influenced by soil, with the strongest effects seen in fine sandy loam. Semolina flour alone reduced root growth of all target plants except for velvetleaf in silt loam. Green foxtail seed germination was greatly reduced by strain G2-11. With the exception of wheat seedling growth, strain G2-11 enhanced growth-suppressive qualities of semolina flour. Results suggest that natural plant products such as CGM and semolina flour alone and formulated with
\end{abstract}

Received 7 April 2004, Accepted 2 September 2004

Address correspondence to Robert J. Kremer, USDA-ARS, 302 ABNR Bldg., University of Missouri, Columbia, MO 65211, USA. E-mail: KremerR@missouri.edu 
selected DRB may be important components for weed management considerations in sustainable agriculture.

Keywords: Corn gluten, natural plant products, semolina, seed germination, rhizobacteria

\section{INTRODUCTION}

The use of natural products as inhibitors of weed seed germination has been an area of interest as an alternative to synthetic herbicides (Lydon and Duke 1987). A well-characterized inhibitory material is corn gluten meal (CGM), a by-product from corn wet-milling. CGM inhibits germination and emergence of a wide variety of weed species and has been used to effectively reduce infestations of weeds such as foxtail (Setaria spp.) and velvetleaf (Bingaman and Christians 1995; McDade and Christians 2000). Enzymatic hydrolysis of CGM produces a product that is highly herbicidal due to the presence of root-inhibiting dipeptides (Liu and Christians 1994; 1996; 1997). Efforts to improve the efficacy of CGM products have involved amending the product with other herbicidal agents. CGM combined with pendimethalin at sublethal levels resulted in superior control of large crabgrass (Digitaria sanguinalis [L.] Scop.) compared with CGM alone (Gardner, Christians, and Bingaman 1985).

An attractive approach for improving performance of weed control agents is the use of rhizobacteria with deleterious activity toward weed seedling growth. Soil amendment with selected DRB has been successfully used for suppressing downy brome (Bromus tectorum L.), Japanese brome (B. japonicum Thumb. ex Murr.), and jointed goatgrass (Aegilops cylindrica Host.) in wheat fields (Kennedy et al. 1991; Harris and Stahlman 1996). A DRB strain of Pseudomonas fluorescens formulated in a "Pesta" product suppressed green foxtail emergence by as much as $90 \%$ (Daigle, Connick, and Boyetchko 2002). Furthermore, the efficacy of soil-applied herbicides has been enhanced with the addition of DRB (Kremer and Kennedy 1996). Growth-suppressive effects of DRB toward weeds depend on the ability of the organisms to populate the root environment and to colonize the root surfaces. The multiplication and survival of DRB are greatly affected by environmental factors (Kremer and Kennedy 1996). Soil moisture, soil texture, and composition of host plant root exudates influence colonization of the rhizosphere and rhizoplane (Howie and Echandi 1983). Fredrickson and Elliott (1985) found that root colonization was similar over a range of root zone temperatures but was dependent on soil type, with higher populations developing in soils with lower organic matter content. Few studies have focused on the influence of soil properties on the suppressive activity of DRB and natural plant products applied as a weed management tactic (Li, Kremer, and Ross 2002). The objectives of this study were to characterize 
the activity of DRB and two formulation agents in different soils and to examine the potential of DRB in promoting the growth suppressive nature of formulation components.

\section{MATERIALS AND METHODS}

\section{Soils and Organisms}

Experiments were conducted by using two different soils: 1) Shoals silt loam (fine-loamy, mixed, non-acid, mesic Aeric Fluvaquents) obtained from a cultivated field (Berrien County, MI) that had not been treated with herbicides the previous growing season and 2) Kaintuck fine sandy loam (coarse-loamy, siliceous, non-acid, mesic, Typic Udifluvents) from Osage County, Missouri, that had not been in cultivation for 10 years. Surface bulk soil samples (0- to 10-cm depth) were collected by using a stainless steel probe along transects established at each site. Three sampling points were selected along the transect from which a minimum of three soil cores were collected, mixed, and stored in open plastic bags at $15-20^{\circ} \mathrm{C}$ until processing. Characteristics for both soils are found in Table 1. The samples of both soils were air dried and sieved prior to setting up the studies. Total culturable populations of soil bacteria were determined by spread plating soil dilutions on one-tenth strength tryptic soy agar. The selected DRB strain Pseudomonas fluorescens G2-11 originated from roots of giant foxtail (Setaria faberi Herrm.) and was phytotoxic based on lettuce (Lactuca sativa L.) and green foxtail seedling bioassays ( $\mathrm{Li}$ and Kremer 2000). Commercially available semolina flour and corn gluten meal were used as inoculant carriers and as natural plant products applied directly to the soils.

\section{Seedling Assays}

DRB isolate G2-11 was cultured in half-strength King's B (KB) broth (King, Ward, and Raney 1954) on a rotary shaker $(250 \mathrm{rpm})$ at $28^{\circ} \mathrm{C}$ for $18 \mathrm{~h}$. Cells

Table 1. Properties of soils used

\begin{tabular}{lccccccc}
\hline & & & & & & & \\
Soil & $\mathrm{pH}_{\mathrm{s}}$ & $\begin{array}{c}\mathrm{OM} \\
(\%)\end{array}$ & $\begin{array}{c}\mathrm{P} \\
\left(\mathrm{m} \mathrm{kg}^{-1}\right)\end{array}$ & $\begin{array}{c}\mathrm{Ca} \\
\left(\mathrm{mg} \mathrm{kg}^{-1}\right)\end{array}$ & $\begin{array}{c}\mathrm{Mg} \\
\left(\mathrm{mg} \mathrm{kg}^{-1}\right)\end{array}$ & $\begin{array}{c}\mathrm{K} \\
\left(\mathrm{mg} \mathrm{kg}^{-1}\right)\end{array}$ & $\begin{array}{c}\text { Bacterial } \\
\text { pofulation } \\
\mathrm{coil}^{-1}\end{array}$ \\
\hline $\begin{array}{l}\text { Silt } \\
\text { loam }\end{array}$ & 7.2 & 2.3 & 47 & 1,063 & 319 & 123 & $4.6 \times 10^{5}$ \\
$\begin{array}{l}\text { Fine } \\
\text { sandy }\end{array}$ & 7.2 & 2.7 & 199 & 1,700 & 263 & 133 & $1.4 \times 10^{6}$ \\
loam & & & & & & & \\
\hline
\end{tabular}


were harvested by centrifugation $\left(8000 \times g\right.$ for $20 \mathrm{~min}$ at $\left.8^{\circ} \mathrm{C}\right)$, supernatant decanted, and resuspended in sterile half-strength $\mathrm{KB}$ broth at $1 / 100$ original culture volume. The cell suspension was mixed in a Waring blender with semolina flour or CGM in a $1: 5$ ratio $(\mathrm{mL}: \mathrm{g})$ based on the process of Connick et al. (1991). Control formulations lacking G2-11 were prepared as above with sterile KB broth. After air drying at $29^{\circ} \mathrm{C}$ for $20 \mathrm{~h}$, the preparations were passed through a 1-mm mesh sieve and stored in sealed plastic test tubes at $4{ }^{\circ} \mathrm{C}$. Populations of viable $\mathrm{G} 2-11$ cells in the inoculant were determined by spread plating on half-strength $\mathrm{KB}$ agar after thorough suspension and dilution in $0.1 \%$ peptone. Formulations were used within 2 weeks of preparation, and numbers of viable cells were determined over an 8-week period.

Soil $(100 \mathrm{~g})$ was mixed with $1 \mathrm{~g}$ of formulation $\left(1.5 \times 10^{8} \mathrm{CFU}\right)$ and distributed into a square $9 \times 9 \mathrm{~cm}$ polystyrene dish, which translates to a rate of $125 \mathrm{~g} \mathrm{~m}^{-2}$, an intermediate inoculation rate used in field studies (Daigle, Connick, and Boyetchko 2002). Sterile distilled water was added to $80 \%$ water-holding capacity (WHC) and surface-disinfested seeds of velvetleaf, green foxtail, or wheat cv "Coker 9474" were sown to a depth of about 2 $\mathrm{mm}$. Twenty to thirty seeds were used per plate, depending on plant species. The plates were sealed with film (Parafilm ${ }^{\mathrm{TM}}$ ) and maintained in the dark at $29^{\circ} \mathrm{C}$ for $48 \mathrm{~h}$. To examine the effect of a liquid suspension of G2-11 cells on seed germination and growth, G2-11 cells were cultured and processed as described above. A suspension of $1.5 \times 10^{8} \mathrm{CFU}$ in sterile distilled water was applied to each soil plate at a volume to achieve $80 \%$ WHC and maintained in the same way as plates receiving a granular formulation. After incubation, seed germination was determined and seedling root lengths were measured. Because of difficulty in distinguishing between shoot and root in stunted velvetleaf plants, the entire length from cotyledon to root tip was measured for all velvetleaf plants. Plates were set up in duplicate, and the experiments were repeated twice.

\section{DRB Inhibition Assay}

To test if CGM and semolina were inhibitory to G2-11, half-strength KB agar plates were spread with G2-11 cells, and 5-mm-diameter wells were made by removing a plug of agar. Wells were filled with sterile distilled water, $50 \mathrm{mg}$ of semolina flour moistened with sterile distilled water, or $50 \mathrm{mg}$ of CGM moistened with sterile distilled water. After incubation at $29^{\circ} \mathrm{C}$ for $24 \mathrm{~h}$, any zones of inhibition were noted. The assay was performed in triplicate.

\section{Statistical Analysis}

Results of the bioassays for each indicator seedling were subjected to two-way analysis of variance in which the factors were soil (independent variable) and 
natural herbicide (dependent variable). Data expressed as percentage were arc-transformed prior to analysis and converted back to percentage for presentation purposes. Means were separated with Fisher's Protected LSD at $p=0.05$ (SAS 1996).

\section{RESULTS}

Viable numbers of G2-11 formulated in semolina averaged $1.5 \times 10^{8} \mathrm{~g}^{-1}$ and were stable for at least 8 weeks at $4^{\circ} \mathrm{C}$. Attempts at formulating G2-11 in CGM failed to generate formulations with viable G2-11 cells (minimal level detected: $200 \mathrm{cfu} \mathrm{g}^{-1}$ formulation). Results from the DRB inhibition assay indicated that CGM, but not semolina, was inhibitory to G2-11 (mean diameter of zone of inhibition: $11 \mathrm{~mm}, \mathrm{~N}=3$ ) showing that CGM directly inhibited G2-11 growth.

All seed species germinated greater than $70 \%$ in soils that received no amendments (Table 2). Velvetleaf was the most vigorous, germinating greater than $90 \%$ with all amendments except the liquid G2-11 treatment. Modest decreases in wheat seed germination were noted in both soils amended with semolina. The interaction between soil and formulation for green foxtail seed germination was significant $(p<0.05)$. Green foxtail seed germination was consistent across all granular amendments in silt loam. However, liquid suspensions of G2-11 reduced green foxtail seed germination similar to results of previous work (Li and Kremer 2000). In contrast, semolina-lacking G2-11 slightly decreased green foxtail germination in fine sandy loam. Both corn gluten meal and liquid G2-11 suspensions

Table 2. Seed germination in silt loam and fine sandy loam soils in the presence of various soil amendments

\begin{tabular}{|c|c|c|c|c|c|c|}
\hline \multirow[b]{2}{*}{ Treatment } & \multicolumn{6}{|c|}{ Germination \% $( \pm$ SEM $)$} \\
\hline & None & Semolina & $\begin{array}{c}\text { Semolina }+ \\
\text { G2-11 }\end{array}$ & CGM & $\begin{array}{c}\text { Liquid + } \\
\text { G2-11 }\end{array}$ & $\begin{array}{l}\text { LSD } \\
(0.05)\end{array}$ \\
\hline \multicolumn{7}{|l|}{ Silt loam } \\
\hline Wheat & $93 \pm 3$ & $75 \pm 17$ & $81 \pm 10$ & $80 \pm 8$ & $69 \pm 13$ & 16.8 \\
\hline Velvetleaf & $93 \pm 7$ & $96 \pm 3$ & $93 \pm 2$ & $98 \pm 2$ & $76 \pm 6$ & 6.8 \\
\hline $\begin{array}{l}\text { Green } \\
\quad \text { foxtail }\end{array}$ & $76 \pm 8$ & $82 \pm 7$ & $65 \pm 6$ & $71 \pm 7$ & $21 \pm 9$ & 11.6 \\
\hline \multicolumn{7}{|l|}{ Fine sandy } \\
\hline Wheat & $86 \pm 5$ & $73 \pm 5$ & $74 \pm 9$ & $86 \pm 9$ & $75 \pm 6$ & 10.2 \\
\hline Velvetleaf & $93 \pm 5$ & $98 \pm 2$ & $95 \pm 4$ & $98 \pm 2$ & $75 \pm 3$ & 8.2 \\
\hline $\begin{array}{l}\text { Green } \\
\text { foxtail }\end{array}$ & $70 \pm 9$ & $52 \pm 13$ & $8 \pm 4$ & $39 \pm 26$ & $38 \pm 8$ & 21.4 \\
\hline
\end{tabular}


reduced green foxtail seed germination to about $55 \%$ of germination noted in the absence of amendments. Only $8 \%$ of green foxtail germinated in soil amended with G2-11-inoculated semolina.

The interaction between soil and formulation for seedling growth of all plant species was significant $(p<0.05)$. Root growth of the three plant species differed according to soil and amendment. In the absence of any amendment, root growth was greatest in the fine sandy loam. With the exception of velvetleaf in the silt loam, semolina alone as an amendment reduced root growth (Figure 1-3). The largest decreases in root length due to the semolina flour were found in fine sandy loam. Wheat and green foxtail root lengths decreased to $45 \%$ and $50 \%$, respectively, of the control in the presence of semolina flour (Figures 1 and 2). Strain G2-11 combined with semolina had variable effects on root growth. Growth of wheat roots in semolina-amended soil did not decrease significantly with the addition of strain G2-11 (Figure 1). However, several of the wheat roots in the presence of strain G2-11 had brown root tips in contrast to healthy white root tips in the absence of G2-11. Velvetleaf roots were also abnormal in G2-11-inoculated soil. In fine sandy loam, velvetleaf roots were greatly stunted relative to plants in soil amended with semolina lacking G2-11 (Figure 3). The majority (82\%) of velvetleaf roots were greater than $30 \mathrm{~mm}$ in length when growing in nonamended soil. This number decreased to $1 \%$ in the presence of strain G2-11. Growth suppression of velvetleaf was less severe in silt loam. Green foxtail roots in the presence of G2-11 were

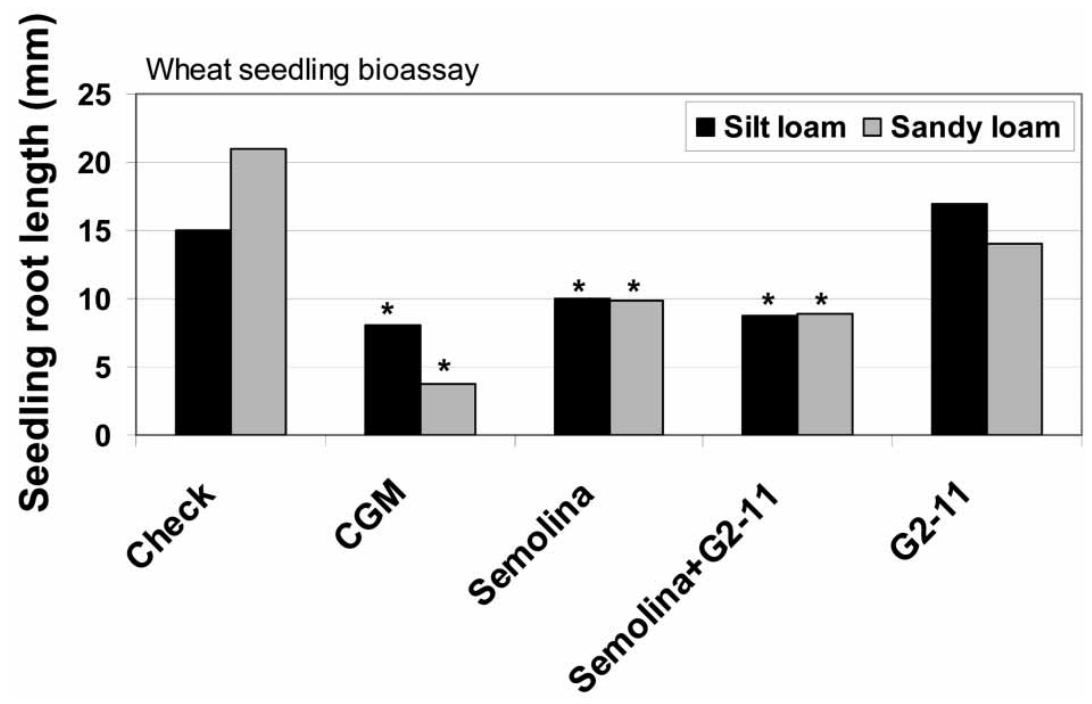

Figure 1. Effect of soil amendment on wheat root length. Means represented by a column designated with $\left(^{*}\right)$ are significantly $(p<0.05)$ different from the check within the same soil based on Fisher's protected LSD. 


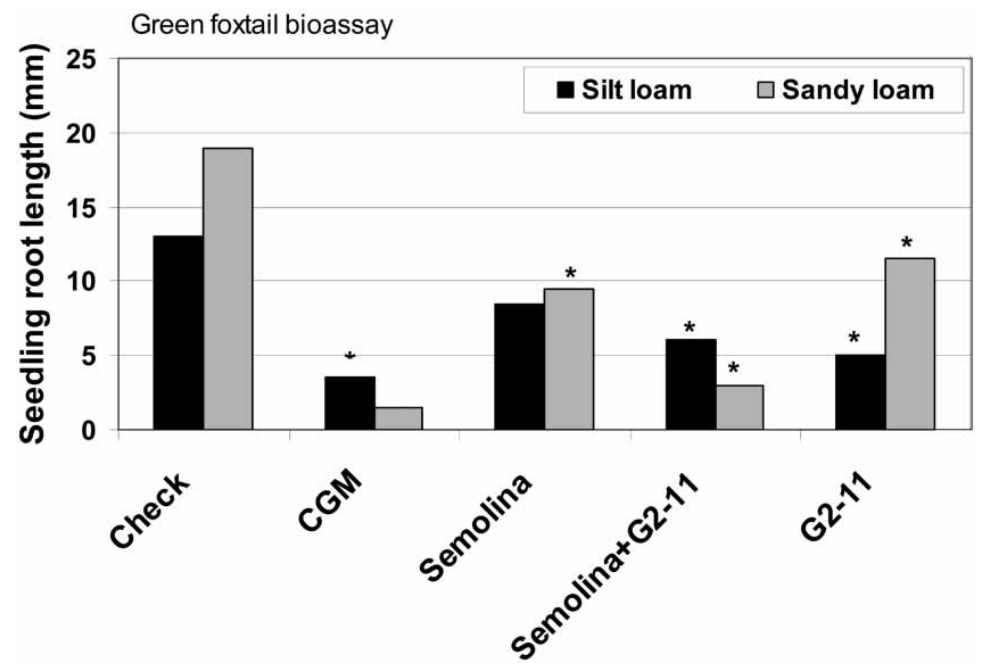

Figure 2. Effect of soil amendment on green foxtail root length. Means represented by a column designated with $\left({ }^{*}\right)$ are significantly $(p<0.05)$ different from the check within the same soil based on Fisher's protected LSD.

$13 \%$ the length of roots in fine sandy loam (Figure 2) containing no amendment. Only $5 \%$ of green foxtail roots growing in nonamended soil were less than $5 \mathrm{~mm}$ in length compared o $100 \%$ of the plants in G2-11amended soil. Of the three plant species, G2-11 suspensions significantly

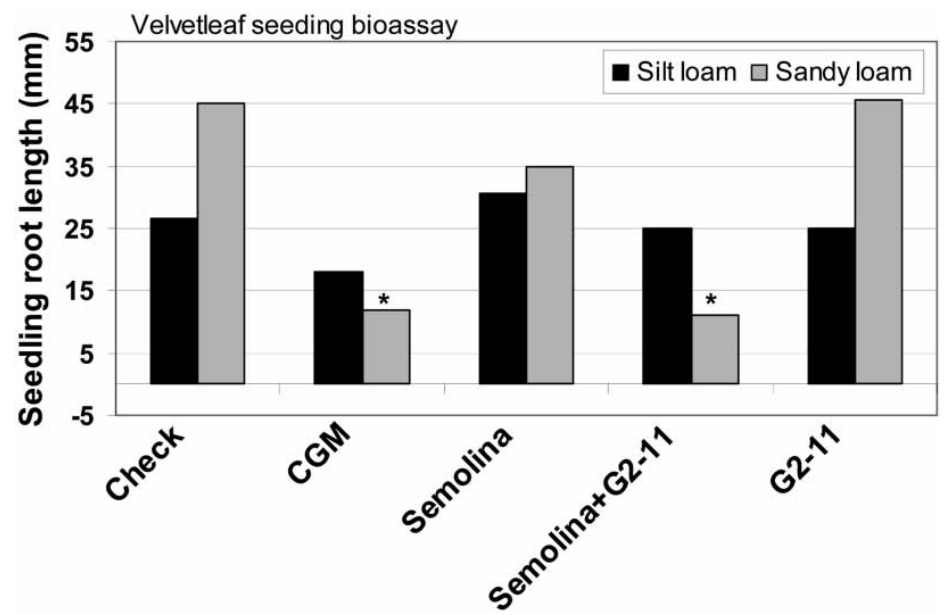

Figure 3. Effect of soil amendment on velvetleaf root length. Means represented by a column designated with $\left(^{*}\right)$ are significantly $(p<0.05)$ different from the check within the same soil based on Fisher's protected LSD. 
reduced root growth of only green foxtail in both soils. Semolina combined with G2-11 applied to fine sandy loam soil significantly inhibited root growth compared to either semolina or G2-11 applied individually (Figure 2). Such synergistic inhibition of green foxtail by semolina and G2-11 was equivalent to inhibition by CGM.

CGM severely inhibited wheat root growth in fine sandy loam (Figure 1). In contrast, strain G2-11 and CGM reduced wheat root growth equally in silt loam. When grown in the presence of CGM, wheat root tips were discolored, resembling effects with strain G2-11. With velvetleaf, CGM was more effective than G2-11 in reducing root growth in silt loam but not in fine sandy loam (Figure 3 ). The majority of velvetleaf roots $(88 \%)$ grown in fine sandy loam was less than $5 \mathrm{~mm}$ long in the presence of CGM compared to $8 \%$ of roots in the absence of CGM. Abnormal velvetleaf root morphology such as browning, severe twisting, and tissue softening was noted in plants growing in CGM-amended soil. CGM inhibited green foxtail root growth greater than G2-11 in both soils; roots averaged 1.4 and $3.3 \mathrm{~mm}$ in fine sandy loam and silt loam, respectively (Figure 2).

\section{DISCUSSION}

Soil incorporation of formulated biocontrol agents is an approach that has proved superior to soil surface application of CGM or bacterial amendments (Mazzola, Stahlman, and Leach 1995; Nonnecke and Christians 1993). In previous studies, CGM inhibited giant foxtail root growth more than velvetleaf (Bingaman and Christians 1995), which supported results reported here (Figures 2 and 3). Corn grain also contains antibacterial peptides (Duvick et al. 1992), which may contribute to inhibitory activity of CGM against strain G2-11 when formulated together. Formulation ingredients should not be toxic toward inoculant microorganisms (Greaves, Holloway, and Auld 1998); therefore, on the basis of our results, CGM is not recommended as a carrier in formulations containing G2-11. Our results also emphasize the importance of prescreening formulation ingredients for effects on growth of inoculant bacteria.

Wheat gluten meal may inhibit seed germination, partly explaining suppressive effects of semolina on wheat germination (Liu, Christians, and Garbutt 1994; Gough and Carlstrom 1999) In addition, inhibition of seedling growth by uninoculated semolina formulations was similar to reported effects of wheat gluten meal on root growth of various weed species (Gough and Carlstrom 1999). The basis for toxicity is not known but may involve toxic peptides such as thionins, which occur in wheat seed (Bohlmann and Apel 1991). Alternatively, semolina flour may stimulate growth or activity of deleterious soil microorganisms that suppress root growth. 
Growth inhibition of grasses by pseudomonads may be influenced by soil type (Horwath, Elliott, and Lynch 1998). The low clay mineral content of the fine sandy loam may favor activity of G2-11 against green foxtail because of reduced interference of clay with phytotoxic substances. However, other reports suggest that soils with high clay content generally favor rhizobacterial activity (Stutz, Kahr, and DeFago 1989). It is possible that in soils of different clay content and mineralogy, suppressive activity of introduced bacteria and phytotoxicity of natural product amendments may be influenced by formulation composition and characteristics of the selected bacterial strain. For example, Pseudomonas fluorescens DRB strains formulated in semolina, used in South Dakota for control of leafy spurge (Euphorbia esula L.), effectively colonized roots similarly at all sites, even though soils at each site differed in clay contents (Brinkman, Clay, and Kremer 1999).

These results demonstrated that germination- and growth-suppressive characteristics of wheat- and corn-derived products and weed biocontrol potential of G2-11 may be valuable qualities in biologically based weed management systems. Synergism between CGM and DRB in reducing green foxtail seed germination and root growth influenced by soil properties has been documented for the first time. DRB amendment for weed suppression was comparable to CGM in reducing velvetleaf growth and superior to CGM in reducing green foxtail germination in fine sandy loam yet did not suppress wheat growth in either soil. Microbial inoculants for weed control may perform best under specific soil conditions, thus influencing their use in integrated weed control strategies. Designing CGM-based weed control practices that are compatible with microbial inoculants, specific soil conditions, and not harmful to the growing crop would further extend the usefulness of both agents.

\section{ACKNOWLEDGMENTS}

We thank Lynn Stanley for providing technical assistance. Trade names are used for clarity and do not represent endorsement by USDA-ARS, the University of Missouri, or Andrews University.

\section{REFERENCES}

Bingaman, B. and Christians, N. (1995) Greenhouse screening of corn gluten meal as a natural control product for broadleaf and grass weeds. Horticultural Science, 30: $1256-1259$.

Bohlmann, H. and Apel, K. (1991) Thionins. Annual Review of Plant Physiology and Plant Molcular Biology, 42: 227-240.

Brinkman, M., Clay, S.A., and Kremer, R.J. (1999) Influence of deleterious rhizobacteria on leafy spurge (Euphoria esula) roots. Weed Technology, 13: 835-839.

Connick, W.J., Jr., Boyette, C.D., and McAlpine, J. (1991) Formulation of mycoherbicides using a pasta-like process. Biological Control, 1: 281-287. 
Daigle, D.J., Connick, W.J., Jr., and Boyetchko, S.M. (2002) Formulating a weedsuppressive bacterium in "Pesta.". Weed Technology, 16: 407-413.

Duvick, J., Rood, S., Rao, A., and Marshak, D. (1992) Purification and characterization of a novel antimicrobial peptide from maize (Zea mays L.) kernels. Journal of Biological Chemistry, 267: 18814-18820.

Fredrickson, J.K. and Elliott, L.F. (1985) Colonization of winter wheat roots by inhibitory rhizobacteria. Soil Science Society of America Journal, 49: 1172-1177.

Gardner, D., Christians, N., and Bingaman, B. (1985) Pendimethalin and corn gluten meal combinations to control turf weeds. Crop Science, 37: 1875-1877.

Gough, R. and Carlstrom, R. (1999) Wheat gluten meal inhibits germination and growth of broadleaf and grassy weeds. Horticultural Science, 34: 269-270.

Greaves, M., Holloway, P., and Auld, B. (1998) Formulation of microbial herbicides. In Formulation of Microbial Biopesticides, Beneficial Microorganisms; Nematodes and Seed Treatments; Burges, H.D., ed.; Kluwer Academic Publishers: Dordrecht, Netherlands, 203-233.

Harris, P. and Stahlman, P. (1996) Soil bacteria as selective biological control agents for winter annual grass weeds in winter wheat. Applied Soil Ecology, 3: 275-281.

Horwath, W., Elliott, L.F., and Lynch, J.M. (1998) Influence of soil quality on the function of inhibitory rhizobacteria. Letters in Applied Microbiology, 26: 87-92.

Howie, W. and Echandi, E. (1983) Rhizobacteria, Influence of cultivar and soil type on plant growth and yield of potato. Soil Biology and Biochemistry, 15: 127-132.

Kennedy, A.C., Elliott, L.F., Young, F.L., and Douglas, C.D. (1991) Rhizobacteria suppressive to the weed downy brome. Soil Science Society of America Journal, 55: $722-727$.

King, E., Ward, M., and Raney, D. (1954) Two simple media for the demonstration of pyocyanin and fluorescein. Journal of Laboratory and Clinical Medicine, 44: 301-307.

Kremer, R.J. and Kennedy, A.C. (1996) Rhizobacteria as biocontrol agents of weeds. Weed Technology, 10: 601-609.

Li, J. and Kremer, R.J. (2000) Rhizobacteria associated with weed seedlings in different cropping systems. Weed Science, 48: 734-741.

Li, J., Kremer, R.J., and Ross, L.R., Jr. (2002) Electron microscopy of root colonization of Setaria viridis by deleterious rhizobacteria as affected by soil properties. Symbiosis, 32: 1-14.

Liu, D. and Christians, N. (1994) Isolation and identification of root-inhibiting compounds from corn gluten hydrolysate. Journal of Plant Growth Regulation, 13: $227-230$.

Liu, D. and Christians, N. (1996) Bioactivity of a pentapeptide isolated from corn gluten hydrolysate on Lolium perenne L. Journal of Plant Growth Regulation, 15: $13-17$.

Liu, D. and Christians, N. (1997) Inhibitory activity of corn gluten hydrolysate on monocotyledonous and dicotyledonous species. Horticultural Science, 32: 243-245.

Liu, D., Christians, N., and Garbutt, J. (1994) Herbicidal activity of hydrolyzed corn gluten meal on three grass species under controlled environments. Journal of Plant Growth Regulation, 13: 221-226.

Lydon, J. and Duke, S.O. (1987) Progress toward natural herbicides from plants. Herbs Spices and Medicinal Plants Digest, 5: 1-4.

Mazzola, M., Stahlman, P., and Leach, J. (1995) Application method affects the distribution and efficacy of rhizobacteria suppressive of downy brome (Bromus tectorum). Soil Biology and Biochemistry, 27: 1271-1278. 
McDade, M. and Christians, N. (2000) Corn gluten meal- a natural preemergence herbicide, effect on vegetable seedling survival and weed cover. American Journal of Alternative Agriculture, 15: 189-191.

Nonnecke, G. and Christians, N. (1993) Evaluation of corn gluten meal as a natural weed control product in strawberry. Acta Horticulturae, 348: 315-320.

SAS. (1996) SAS/STAT user's guide, Version 6.12 Edition.; SAS Institute: Cary; North Carolina.

Stutz, E., Kahr, G., and DeFago, G. (1989) Clays involved in suppression of tobacco black rot by a strain of Pseudomonas fluorescens. Soil Biology and Biochemistry, 21: $361-366$. 